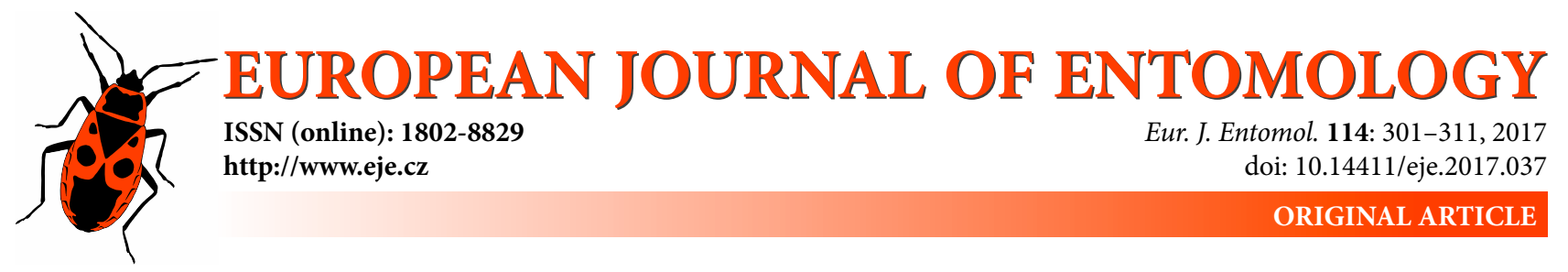

\title{
Acoustic signals of the bush-crickets Isophya (Orthoptera: Phaneropteridae) from Eastern Europe, Caucasus and adjacent territories
}

\author{
Roustem ZHANTIEV, Olga KORSUnOVSKAyA and AleXANDer BENEDIKTOV \\ Department of Entomology, Faculty of Biology, Moscow State University, 119234, Moscow, Leninskie Gory 1-12, Russia; \\ e-mails: zhantiev@mail.ru, korsuno@mail.ru, entomology@yandex.ru
}

Key words. Orthoptera, Phaneropteridae, Barbitistinae, Isophya, acoustic signals, stridulatory files, behaviour

\begin{abstract}
Temporal patterns and frequency spectra of the songs and stridulatory files of 14 species of the genus of the phaneropterid bush-crickets Isophya from Eastern Europe, Altai and the Caucasus are given. The sound signals of the species studied can be separated into three main types: (1) those consisting of two syllables (Isophya gracilis, I. kalishevskii, I. schneideri, I. caspica, Isophya sp. 1); (2) one syllable and series of clicks (I. modesta rossica, I. stepposa, I. taurica, I. brunneri, I. doneciana, I. altaica); (3) single repeating syllables of uniform shape and duration (I. pienensis, Isophya sp. 2 and possibly I. stysi). The acoustic signals and behaviour of eastern European, Altai and Caucasian species are compared to those of several other European species of Isophya.
\end{abstract}

\section{INTRODUCTION}

Phaneropteridae is the largest family of Tettigonioidea. The status of this taxon is currently under discussion and here we follow Heller et al., 1998 and Data base Fauna Europaea (Heller, 2013). According to the Orthoptera Species File, in which this taxon has subfamily rank (Cigliano et al., 2016), it includes more than 2000 species. Most of the species of the subfamily Barbitistinae occur in the Palaearctic. High biodiversity of these bush-crickets can be found in the Mediterranean region. Males of all known Phaneropteridae species produce calling songs, and females of many species respond with sound. The results of the first studies on acoustic communication in Palaearctic species of this group were published in 1977-1981 (Zhantiev \& Dubrovin, 1977; Zhantiev, 1981). Since then acoustic signals of many western European species have been carefully studied (e.g. Heller, 1984, 1988, 1990; Ingrisch, 1991; Ragge \& Reynolds, 1998; Heller et al., 2004; Warchalowska-Sliwa et al., 2008; Iorgu \& Iorgu, 2012; Chobanov et al., 2013, 2017), but songs of species from southeastern Europe, Caucasus and Transcaucasia remain poorly known; sound signals are preliminarily described for only a few phaneropterids from these regions (Zhantiev \& Dubrovin, 1977; Zhantiev \& Korsunovskaya, 1986, 1990, 2005, 2015).

The genus Isophya Brunner von Wattenwyl, 1878 includes more than 80 species (Cigliano et al., 2016). Similarity and variability of morphological characters make many species difficult to identify. The results of recent cytogenetic and molecular genetic studies contradict morphological and bioacoustic data (Warchalowska-Sliwa et al., 2008; Grzywacz-Gibała et al., 2010). We believe that the investigation of the acoustic signals of Isophya males as taxonomic characters could not only be useful for species diagnostics but also provide additional material for a better understanding of the taxonomic position of several species and evolutionary trends in the genus Isophya. Songs of specimens of different species collected in the eastern part of the range of this genus can provide additional data for analysis of the geographical variability in sound signals. Previously data on the songs of several species were published by Zhantiev and co-authors (op. cit.). However, these results do not contain a full description of song structure, frequency spectra and stridulatory files. This article fills these gaps and provides new data about some rare species.

\section{MATERIALS AND METHODS}

Adults or nymphs of different instars of bush-crickets collected in natural habitats were brought to the laboratory where bioacoustic and most behavioural experiments were performed. Tape recordings of the calling song of $I$. doneciana were obtained only in the field. We usually used 3-5 specimens for bioacoustic studies, but in the cases of some rare species only one male was available (see note in the text).

Laboratory tape-recordings of the songs of captured insects were made using 1/4 inch Bruel \& Kjaer 4135 or MK 301 RFT 
microphones with linear characteristics in the range $0.02-100$ kHz, 2604 Bruel \& Kjaer or 00017 RFT microphone amplifier, and modified Yupiter-202 Stereo tape recorder with linear characteristic in the range $0.063-70 \mathrm{kHz}$. The slowest standard tape speed of this tape recorder of $9 \mathrm{~cm} / \mathrm{s}$ was changed to a speed of $38 \mathrm{~cm} / \mathrm{s}$. The calling songs of Isophya doneciana were recorded using a Proton tape recorder $(0.063-10 \mathrm{kHz})$. During recording of the calling song of Isophya sp. 2, a M3-23 tape recorder (2-50 $\mathrm{kHz}$ ) was used. Songs of several species were recorded using the above-mentioned microphone amplifiers connected to A-D converters L-353 and E14-440 (L-card, Russia) of a PC. Most of the song recordings were stored on magnetic tape, digitized using sample frequencies 30303 and/or 58824, 142857 200000/s, and analyzed using the computer programs TurboLab v. 4.2 Bührer \& Partner GbR (Germany) and PowerGraph (DISoft Company, Russia). All the scales of the frequency spectra shown in the figures are linear.

Most laboratory experiments were performed in an anechoic chamber in darkness at $20-26^{\circ} \mathrm{C}$. The microphone was positioned at $8-10 \mathrm{~cm}$ from a singing male.

Scanning electron micrographs of the pars stridens (stridulatory file) were taken using scanning electron microscopes S-405A and CamScan S-2.

The bioacoustic terminology used in this study mostly corresponds to that used by Heller et al. (2004) and Orci \& Heller (2004). The main terms are defined as follows.

Calling song: spontaneous song produced by an isolated male. Syllable: the sound produced by one complete up (opening) and down (closing) stroke of the forewings (tegmina). (Isophya males produce sounds only during the closing stroke.) Hemisyllables: parts of syllable divided in some species by a pause in the down movement of the tegmina. The final hemisyllable is usually a series of clicks. Tooth-impact or click (= impulse according to Heller et al., 2004): short sound impulse arising during contact of a single tooth of the stridulatory file (pars stridens) with the plectrum. After-click: an isolated impulse after the end of the main impulse-group (= click-group), which is the result of the final phase of the closing movement of the tegmina. Series: group of several syllables or clicks. Period (of repetition): the time between the start of one of the repeating units in the temporal structure of a signal and the start of the next fragment of the same type.

\section{RESULTS}

\section{Genus Isophya Brunner von Wattenwyl, 1878}

Most species of this genus are distributed in the Western Palaearctic, especially in the Mediterranean region (BeyBienko, 1954; Harz, 1969; Hochkirch et al., 2016). Up to ten species groups are currently distinguished in this genus: I. costata, I. kraussii, I. major, I. modesta, I. pyrenaea, I. rectipennis, I. schneideri, I. speciosa, I. straubei and I. zernovi (Warchalowska-Sliwa et al., 2008; Unal, 2010; Chobanov et al., 2013, 2017). Several species are known as pests of fruit crops, vine, tobacco etc. Outbreaks and appearance of the gregarious form are sporadically recorded.

\section{Isophya caspica Ramme, 1929}

This species includes two subspecies distributed in western Iran up to Gorgan in the east (the nominative subspecies) and in southeastern Azerbaijan: the Lenkoran lowland and Talysh (I. caspica stshelkanovtzevi Miram, 1938). These subspecies are distinguished by the shape of male cerci. The cerci of the nominative ssp. are curved and more

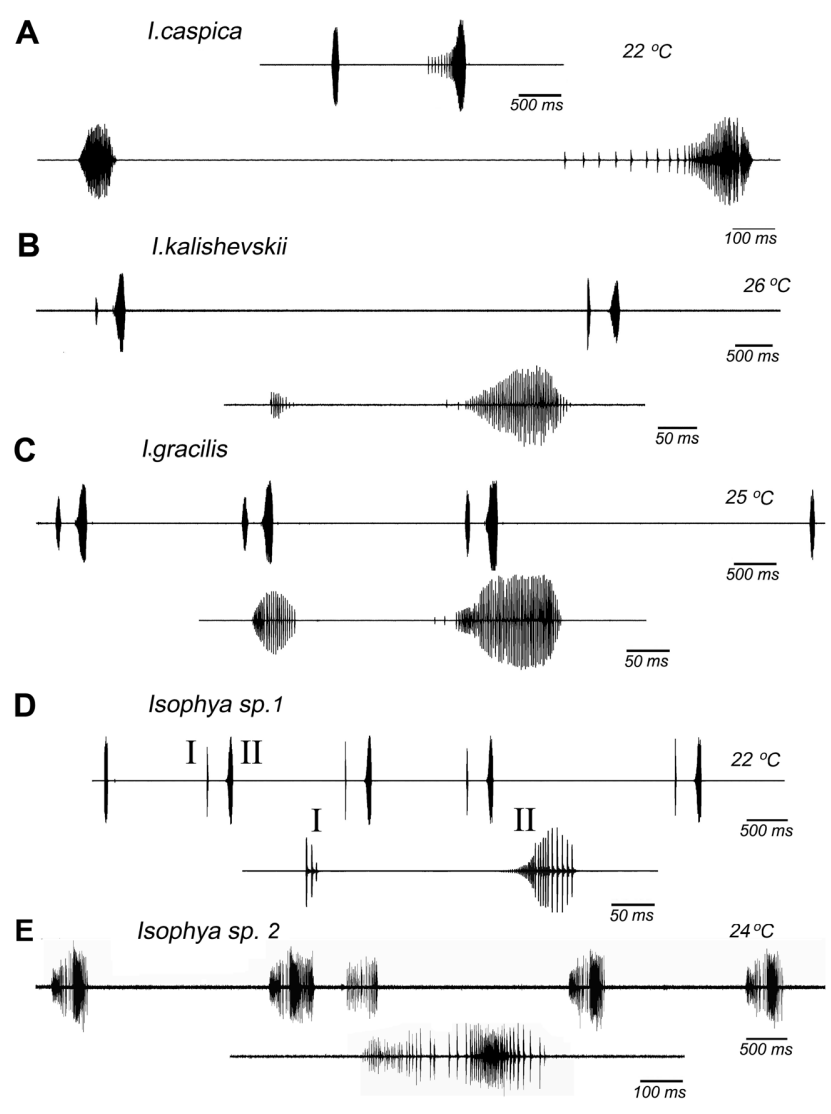

Fig. 1. Oscillograms of the songs of Isophya spp. recorded at two different speeds (time scales below): I. caspica (A); I. kalishevskii (B) I. gracilis (C); Isophya sp. 1 (D); Isophya sp. 2 (E). Air temperature at time of the recording shown on the right.

slender apically. Their shape is similar to those of I. gracilis and I. kalishevskii. Males of I. c. stshelkanovtzevi have less curved cerci, and Bey-Bienko (1954) notes after additional study that its taxonomical status could be changed to a separate species.

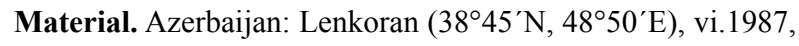
1 male, leg. R. Zhantiev.

Song. We recorded the calling signal of a single male. This sound contains two parts (syllables) (Fig. 1A). The first is a syllable of $83.8 \pm 2.7 \mathrm{~ms}$ duration $(\mathrm{SD}=6.6)$ and the second is more than four times as long and has a more complicated time structure. In the beginning of the second syllable the sound level is low and the repetition rate of tooth-impacts gradually increases during the first 300 ms. Then the sound amplitude increases sharply, reaches a maximum and then at the end sharply decreases. Toothimpact repetition rate in this final part is as high as in the first part of the signal. Total duration of the second part of the signal is $480.3 \pm 23.5 \mathrm{~ms}, \mathrm{SD}=74.2$. The interval between both parts of the song is ca. $1 \mathrm{~s}$.

The frequency spectrum is narrow $(7-22 \mathrm{kHz})$, with dominant frequencies of 12-14 kHz (Fig. 2A).

Pars stridens is slightly curved and bears 78 teeth of uniform shape and density (Fig. 3A). 

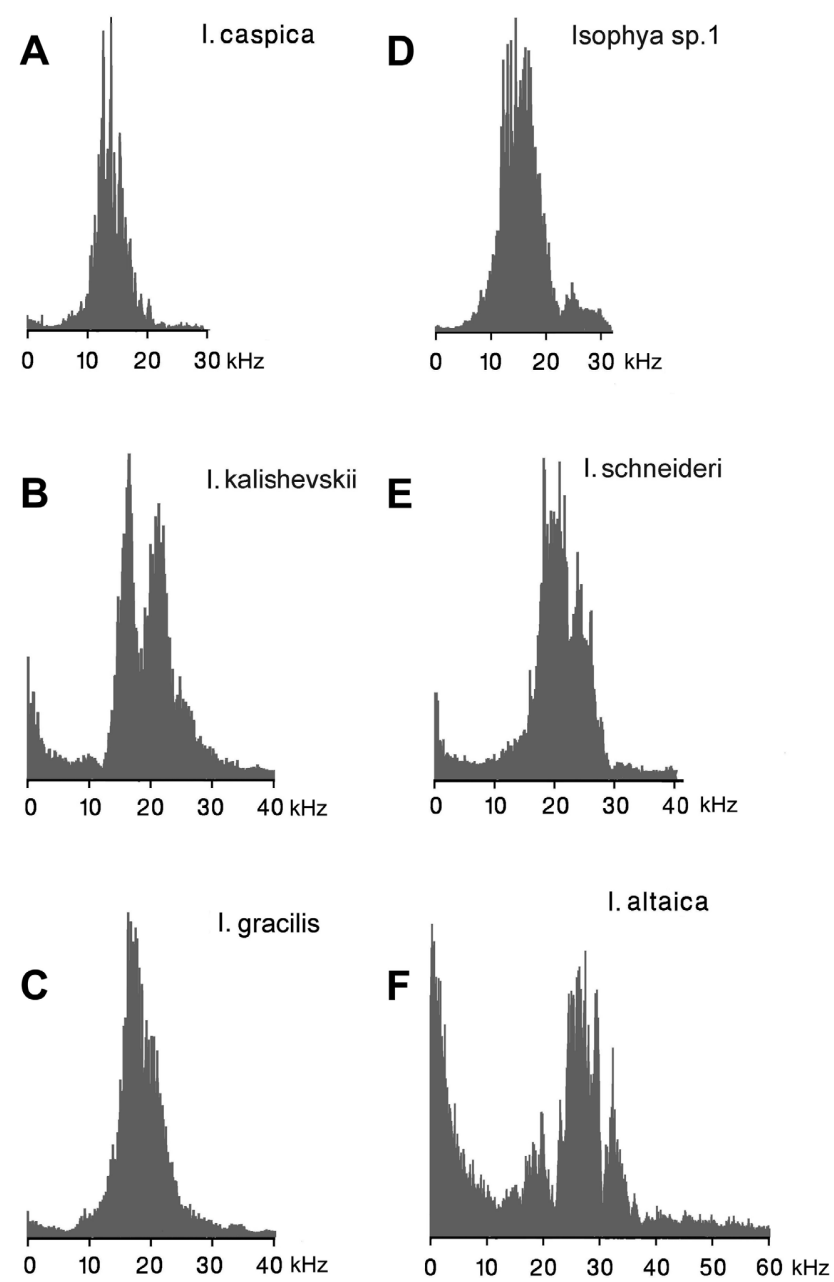

Fig. 2. Frequency spectra of male calling songs of Isophya caspica (A); I. kalishevskii (B), I. gracilis (C); Isophya sp. 1 (D); I. schneideri $(\mathrm{E})$; I. altaica $(\mathrm{F})$. Vertical scale linear.

\section{Isophya kalishevskii Adelung, 1907}

This species is described from Abkhasia (Sukhum distr., Chhalta river, Mt. Marukh) and occurs at Abkhasia and localities near Sochi (Krasnodar territory, Russia).

Material. Abkhasia: locality near lake Ritsa (Avadhara river valley, $\left.43^{\circ} 31^{\prime} \mathrm{N}, 63^{\circ} 17^{\prime} \mathrm{E}\right), 30 . v i i i .1985,1$ male, 1 female, leg. V. Chukanov.

Song. The calling song of the male studied consists of two parts (single syllables), which are divided by an interval lasting $240.8 \pm 7.5 \mathrm{~ms}(\mathrm{SD}=29.0)$ (Fig. 1B). Mean duration of the first syllable is $34.5 \pm 1.2 \mathrm{~ms}(\mathrm{SD}=4.8)$ and the second $-146.6 \pm 1.2 \mathrm{~ms}(\mathrm{SD}=5.0)$.

The frequency spectrum is in a band of up to $40 \mathrm{kHz}$ with two maxima at 15 and $22 \mathrm{kHz}$ (Fig. 2B).

Stridulatory file of the male (Fig. 3B) is slightly curved and bears 78 teeth. Female stridulatory file is depicted in Fig. 3D.

\section{Isophya gracilis Miram, 1938}

This species is very similar to I. kalishevskii and distinguished from it by the rectangular or obtuse posterior margin of the female genital plate. Males of both species are morphologically almost indistinguishable (Bey-Bienko, 1954).

Described from the source of the Belaya river, Mt. Pshekish, and distributed in Ciscaucasia and on the northern slope of the Caucasus mountain range.

Outbreaks of this species occur during which it is a serious pest of forest trees and fruit crops. This species has gregarious and solitary phases. The upper surface of the body of the former is black except for the tegmina and pronotum, which often with light "window". The solitary form is green or mainly green.

Material. Russia: Northern Ossetia, Alagir, 09.ix.1984; 1 male, leg. D. Tishechkin; North Ossetia Nature Reserve, 08.viii.1985, 1 male, leg. D. Tishechkin; Krymsk, v.1988. 3 males, 5 females, leg. D. Lapshin; Stavropol, vi.2010, 3 males, 3 females, leg. A. Semenov.

Song is very similar to that of I. kalishevskii: it consists of two parts (Fig. 1C). Data for 6 males from Krymsk and Stavropol are as follows: duration of the first syllable at 25 and $26^{\circ} \mathrm{C}$ was $50.4 \pm 1.9 \mathrm{~ms}$ and $58.7 \pm 2.2(\mathrm{SD}=13.2$ and 13.6) and the second $-127.9 \pm 1.8 \mathrm{~ms}$ and $128.3 \pm 1.7$ $\mathrm{ms}(\mathrm{SD}=12.9$ and 10.6), with the interval between them $201.8 \pm 3.2 \mathrm{~ms}$ and $160.2 \pm 5.1 \mathrm{~ms}(\mathrm{SD}=22.7$ and 32.0), respectively.

At a lower air temperature $\left(23^{\circ} \mathrm{C}\right.$, males in northern Ossetia) the durations of all the song elements are longer: the first syllable lasts $62.5 \pm 1.9 \mathrm{~ms}(\mathrm{SD}=6.8)$, second $175 \pm$ $4 \mathrm{~ms}(\mathrm{SD}=13.2)$, interval between them $276.4 \pm 6.2 \mathrm{~ms}$ $(\mathrm{SD}=22)$.

The frequency spectrum of the calling song lies within a narrow band of 5-35 kHz, with dominant frequencies around $18 \mathrm{kHz}$ (Fig. 2C).

Stridulatory files of males from the three localities are curved and bear 91-106 teeth $(\mathrm{N}=3)$. Their shape and density are uniform over most of the file (Fig. 3C). The teeth on the lateral edges are slightly smaller than those in the middle. Hereinafter, lateral edge refers to the edge of the tegmen at the base of the wing (in dorsal view of the insect this edge is lateral to the longitudinal axis of the body). Medial edge is on the opposite side. Female file is shown in Fig. 3E.

Behaviour. Earlier observations of the acoustic behaviour of various phaneropterids in Russia and adjacent territories (Zhantiev \& Korsunovskaya, 1986) indicate that females that possess a sound-producing apparatus can either start moving towards the male before they respond by producing a sound, or start moving and responding simultaneously, or remain immobile and produce a sound. In $I$. gracilis the female during phonotaxis starts moving and responding to the male simultaneously. To reveal which parts of the complicated calling song are important for recognition of conspecific males and which trigger the sound response, we earlier carried out a series of experiments on the phonotaxis and sound responses of females of $I$. gracilis to a conspecific's calling song and its models (Korsunovskaya, 2015). In these experiments we varied the number of syllables, their duration and the duration of the interval between them. As a result, it was shown that the first and 

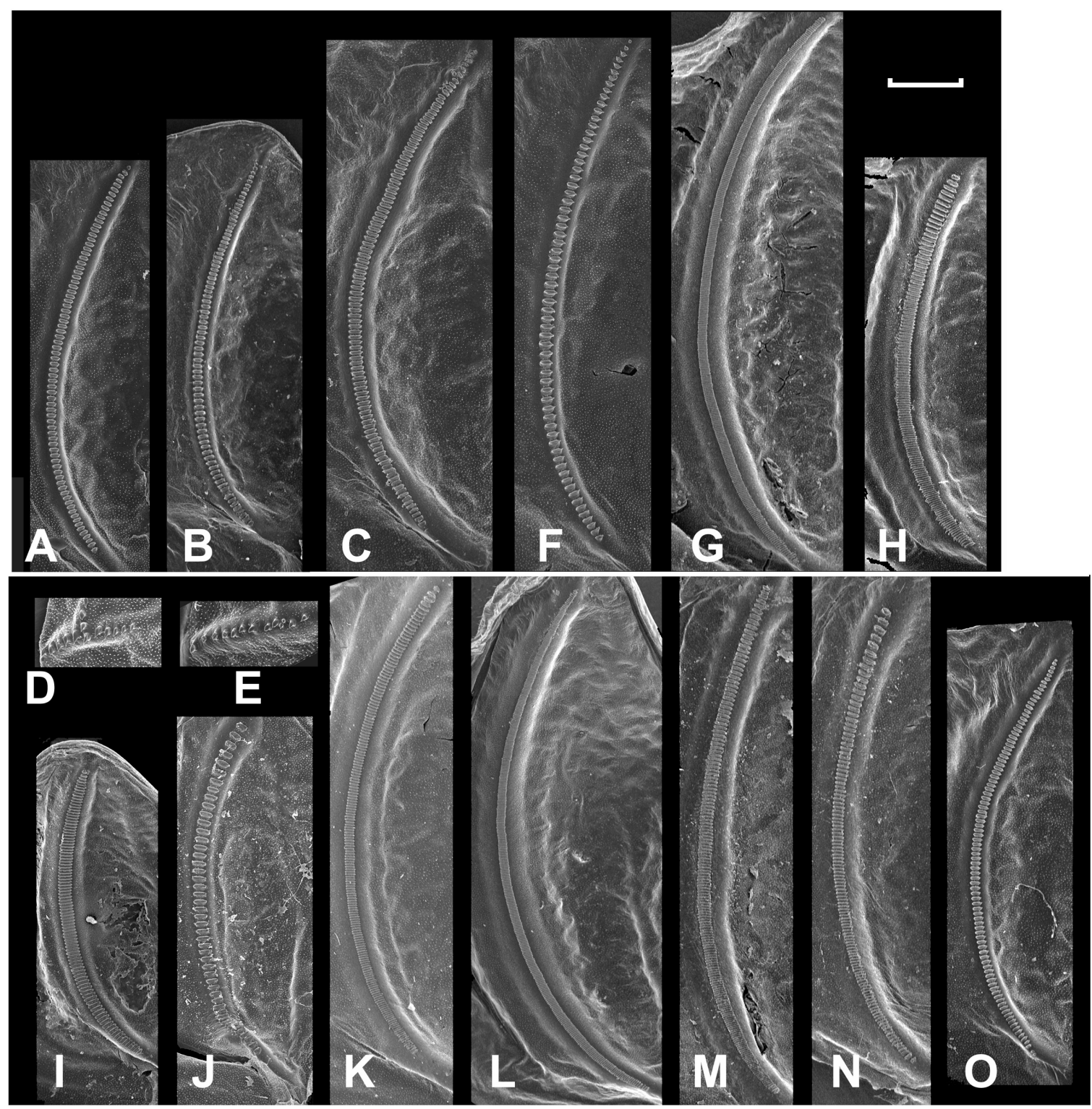

Fig. 3. SEM images of the stridulatory files of males (A-C, F-O) and females (D, E): Isophya caspica (A); I. kalishevskii (B, D); I. gracilis (C, E); Isophya sp. 1 (F); I. schneideri (G); I. altaica (H); I. doneciana (I); I. brunneri (J); I. pienensis (K); I. stepposa (L); I. taurica (M); I. modesta rossica $(\mathrm{N})$; I. stysi $(\mathrm{O})$. Scale bar $500 \mu \mathrm{m}$. Stridulatory file on underside of male left tegmen oriented so that tegmen articulation is below. Articulation of female tegmen is on the right.

second syllables have different roles. This indicates that a short syllable is sufficient to trigger phonotaxis (although the duration of the movement in this case is greater). To initiate the sound response, acoustic stimulation has to be longer; the duration of the first syllable of a conspecific calling song is not sufficient to trigger the sound response of females. This requires a duration of $80-90 \mathrm{~ms}$.

\section{Isophya sp. 1}

This undescribed species is similar to I. gracilis.

Material. Abkhasia: southern Gagra range, Bumbonash area, 3-5 km S Mt. Arbaica $\left(43^{\circ} 24^{\prime} \mathrm{N}, 40^{\circ} 21^{\prime} \mathrm{E}\right)$, vi.2006. 1 male, 1 female, leg. V. Savitsky

Song. As in Isophya kalishevskii and I. gracilis, the male produces a song consisting of two syllables (Fig. 1D). The first is very short: its duration at $22^{\circ} \mathrm{C}$ is $13.5 \pm 1.7 \mathrm{~ms}$
$(\mathrm{SD}=6.5)$; it contains $3-6$ tooth-impacts. The second is significantly longer: $83.5 \pm 2.9 \mathrm{~ms}(\mathrm{SD}=11)$. The repetition rate of tooth-impacts is reduced by half at the end of the second syllable. The pause between the two syllables lasts $211 \pm 2 \mathrm{~ms}(\mathrm{SD}=8.3)$. The intervals between pairs of syllables is $1-2 \mathrm{~s}$.

Frequency spectrum occupies a $5-55 \mathrm{kHz}$ band with dominant frequencies at $12-16 \mathrm{kHz}$ (Fig. 2D). Dominant frequencies of the initial tooth- impacts are lower than these in the final part of the syllable $(13 \mathrm{kHz}$ and $16-17$ $\mathrm{kHz}$ respectively). Tooth-impacts during the first syllable and final loud ones in the second syllable produce similar spectra.

Stridulatory file is slightly curved and bears about 60 evenly distributed uniform teeth (Fig. 3F). Only a few smaller teeth are present on the medial edge of the file. 

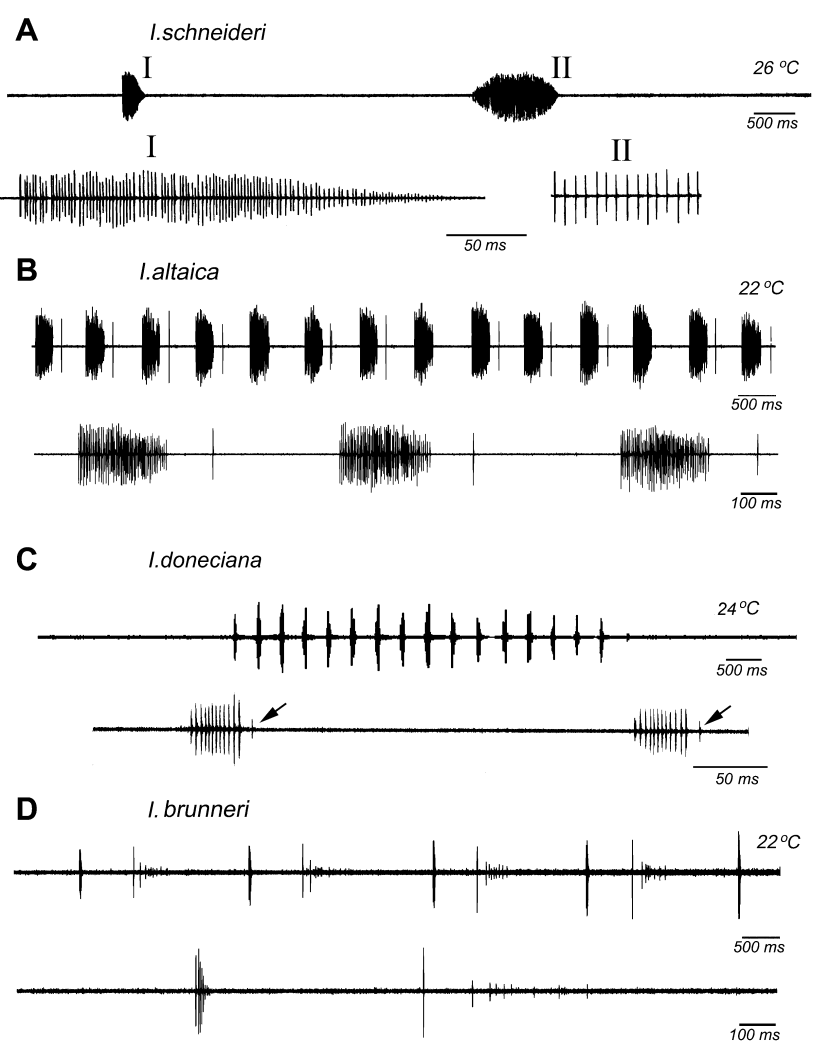

Fig. 4. Oscillograms of the male songs of Isophya spp. recorded at two different speeds (time scales below): I. schneideri (A); I. altaica (B); I. doneciana (C), arrows show second part of song; I.brunneri (D). Air temperature at the time of the recording is shown on the right.

\section{Isophya schneideri Brunner von Wattenwyl, 1878}

This species is widely distributed in the Caucasus and adjacent territories (Daghestan, Azerbaijan, Georgia, Armenia, northeastern Turkey and northwestern Iran). Type locality: Baku (Azerbaijan). Bey-Bienko (1954) notes that the morphological characters are very variable. The taxonomic position of I. schneideri remains a subject of discussion (Sevgili et al., 2012; Chobanov et al., 2017).

Material. Georgia: env. Tbilisi, 17.-24.v.1985, 2 males, 2 females, leg. R. Zhantiev.

Song. Male calling song consists of two syllables of different durations (Fig. 4A). The first lasts $239.3 \pm 6.5$ $(\mathrm{SD}=21.6) \mathrm{ms}$, and the second is significantly longer and more variable in duration: $600-1100 \mathrm{~ms}$. The pause between them lasts 2-4 s. Males often produce only the first part of the signal. In experiments with receptive females the first syllable alone is sufficient for the recognition of the song of a conspecific. If a male produces a single short syllable, females approach but do not produce a sound. A longer syllable is the trigger for the female to produce sound delayed relative to the end of the second syllable of the calling song. The duration of delay is about $400 \mathrm{~ms}$. The threshold intensity of the signal initiating a response in the two females tested was 35-45 dB SPL (at 16-20 $\mathrm{kHz}$ ). In behavioural experiments the shortest duration of the male syllable (at $14-30 \mathrm{kHz}, 80 \mathrm{~dB}$ ) initiating the female sound response was $500 \mathrm{~ms}$.
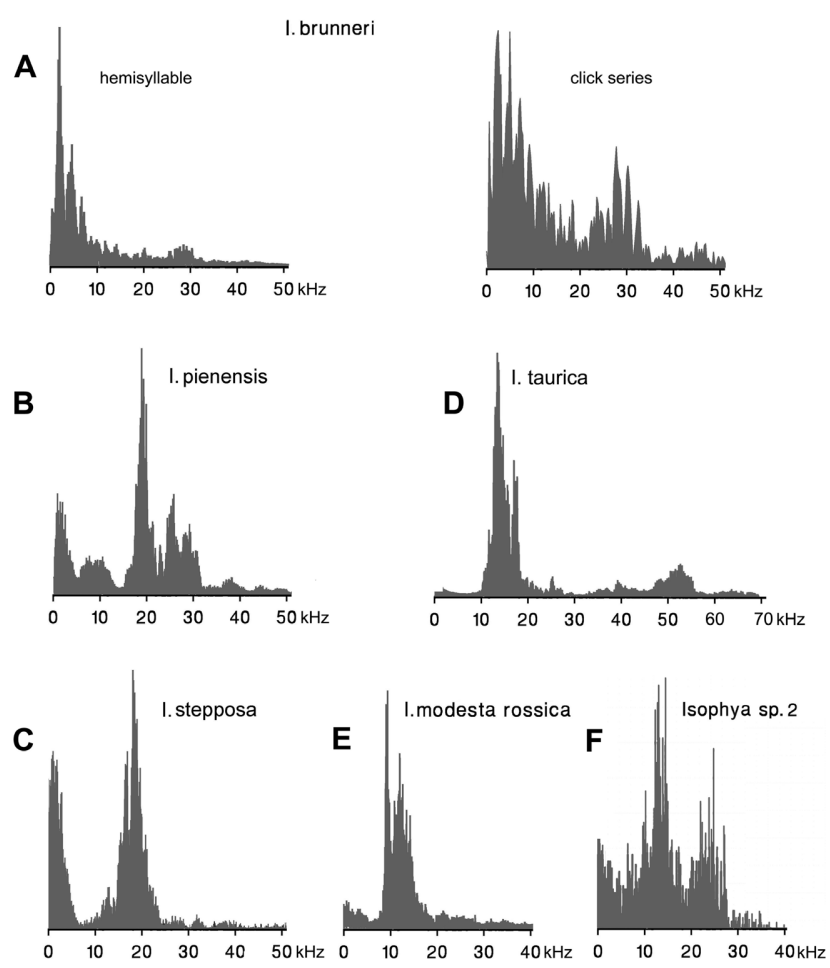

Fig. 5. Frequency spectra of the male calling songs of Isophya brunneri (A), I.pienensis (B), I. stepposa (C); I. taurica (D); I. modesta rossica (E); Isophya sp. 2 (F). Vertical scale linear.

The frequency spectrum of the male song occupies a narrow band between 10 and $30 \mathrm{kHz}$, with dominant frequency at $20 \mathrm{kHz}$ (Fig. 2E).

Male stridulatory file (Fig. 3G) is weakly curved and bears very densely arranged numerous teeth (344 and 258; $\mathrm{N}=2$ ).

\section{Isophya altaica Bei-Bienko, 1926}

(Fig. 6A, B)

The distribution of this species is limited to the Altai Mountains and northeastern Kasakhstan up to Lake Marka-Kul and the Irtysh river in the south. These regions are separated from the distribution area of the other members of this genus by a distance of 2500-3000 km. Thus, I. altaica may be considered a tertiary relict of an early Mediterranean fauna (Bey-Bienko, 1954).

This species is morphologically similar to the West European I. pyrenaea and close in certain characters to the Caucasian species I. zernovi, I. schneideri and I. bivittata (Bey-Bienko, 1954). According to Warchalowska-Sliwa et al. (2008), this species belongs to the I. pyrenaea species group.

Material. Russia: Altai, Ust-Koksinsky district, two km W Chendek village, southern slope of Mt. Selesnek, ca. $1800 \mathrm{~m}$ $\left(50^{\circ} 17^{\prime} \mathrm{N}, 85^{\circ} 57^{\prime} \mathrm{E}\right)$, 5.viii.2001, 2 males, 4 females, leg. A. Benediktov.

Song. Males produce a calling song consisting of a long sequence of uniform two-component signals (Fig. 4B). The rate of the signals is ca. $1.4 \mathrm{~s}^{-1}$ (at $22^{\circ} \mathrm{C}$ ). The first component lasts $237.2 \pm 1.1 \mathrm{~ms}(\mathrm{SD}=5.3)$; the second is a short $(4.1 \pm 0.3 \mathrm{~ms}, \mathrm{SD}=1.3)$ single click (tooth-impact). 

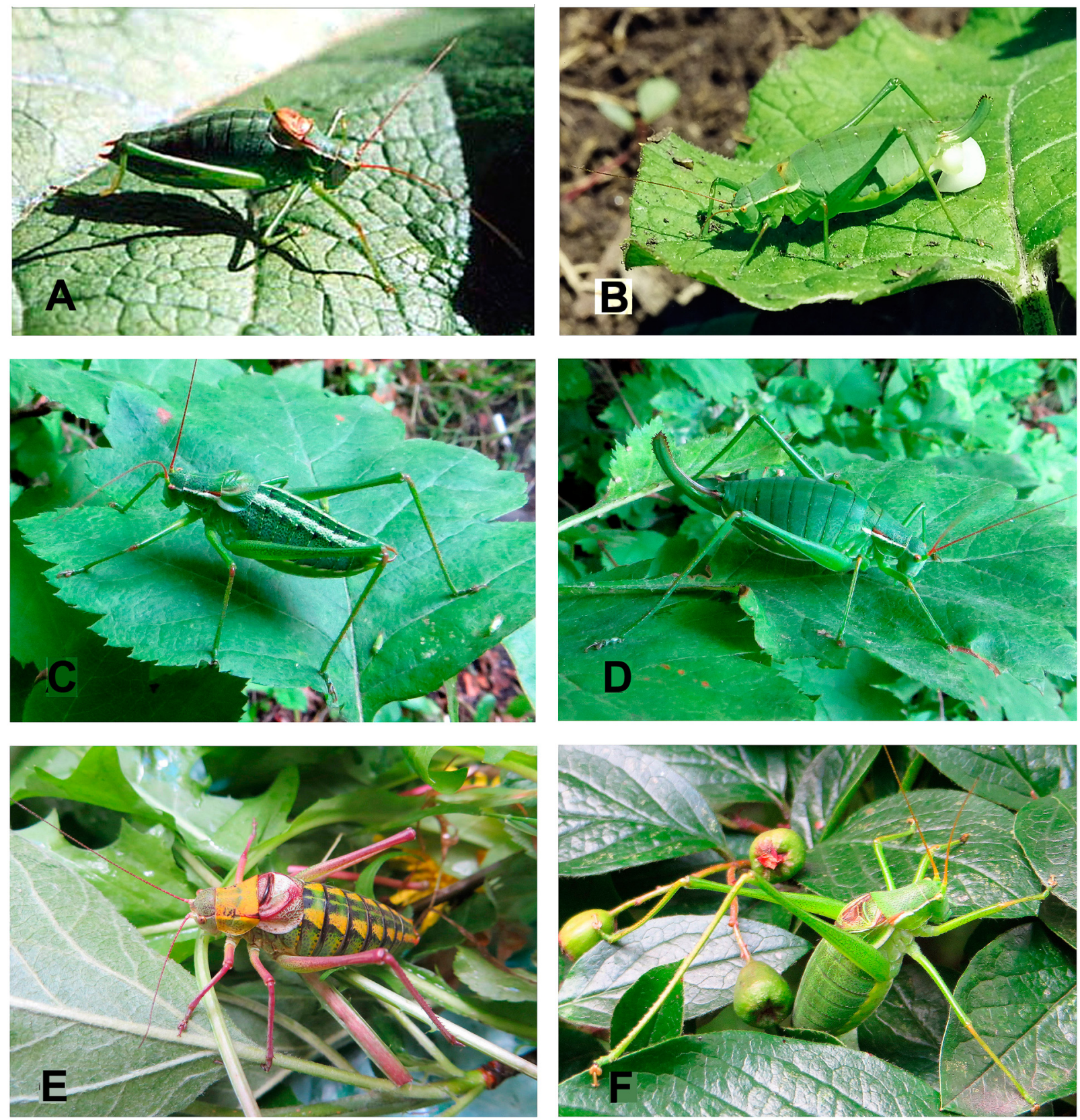

Fig. 6. Male (A) and female (B) of Isophya altaica; male (C) and female (D) of I. stepposa, males of I. taurica (E) and I. modesta rossica (F).

The mean duration of the interval between both parts of the song is $118.4 \pm 1.9 \mathrm{~ms}(\mathrm{SD}=7.9)$.

The main components in the frequency spectra of the male syllable and click lie around $30 \mathrm{kHz}$ (Fig. 2F).

Male stridulatory file is weakly curved and bears 135 teeth with decreasing density towards the medial edge (Fig. 3H).

\section{Isophya doneciana Bei-Bienko, 1954}

Known only from the Donetsk Upland (Provalye) and perhaps endemic to this region. In morphological characters it is similar to I. brunneri, I. zubovskii and I. modestior (Bey-Bienko, 1954). Currently this species is placed in the I. pyrenaea species complex (Chobanov et al., 2013).

Material. Ukraine: Donetsk Province, Provalye, Luhansk Nature Reserve, 11.vi.1996, 1 male, leg. A. Benediktov.
Song of one male was recorded in a natural environment. It produced sequences of clicks (the first part of the song), each of which were followed by one or rarely two very fast clicks (the second part of the song) (Fig. 4C). The duration of the first part is $36 \pm 1 \mathrm{~ms}(\mathrm{SD}=5.3)$; it contains $10-12$ clicks lasting $1.7 \pm 0.1 \mathrm{~ms}$. They are followed by an interval of $3.2 \pm 0.1 \mathrm{~ms}(\mathrm{SD}=0.9)$. The second part of the song consists of one or rarely two clicks weakly expressed with the same duration of clicks as in the first part. Both parts of the song are divided by a pause of $8-17$ ms (mean $12 \pm$ $1 \mathrm{~ms}$ ). Repetition rate of the sequences is ca. $3 \mathrm{~s}^{-1}$. A complete frequency spectrum has not been recorded because the song was recorded by a portable tape-recorder with a frequency band of only up to $10,000 \mathrm{~Hz}$. 
A

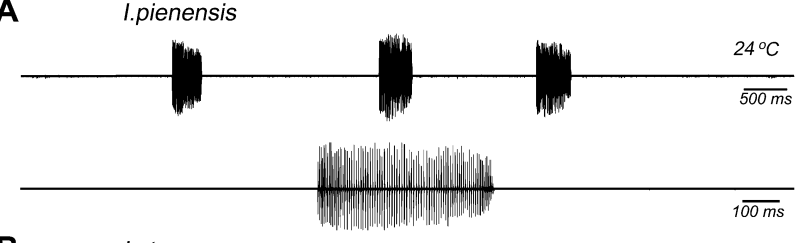

B

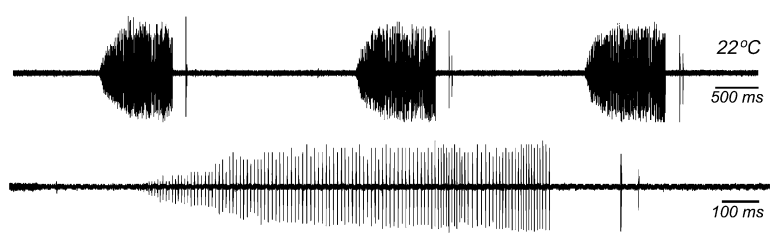

C

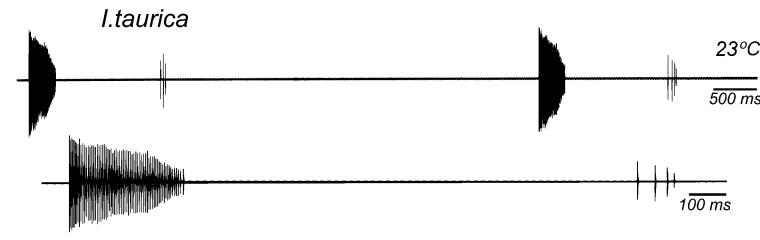

D

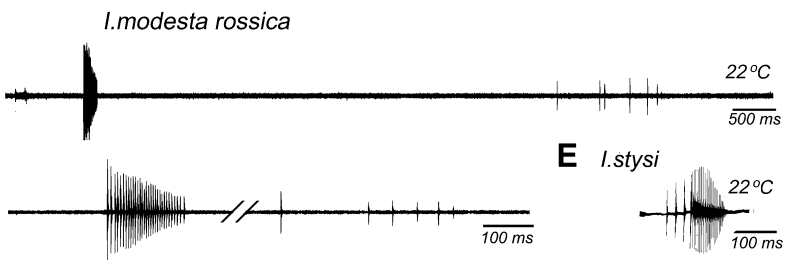

Fig. 7. Oscillograms of the male songs of Isophya spp. recorded at two different speeds (time scales below): I. pienensis (A); I. stepposa (B); I. taurica (C); I. modesta rossica (D); I. stysi (E). Air temperature at the time of the recording is shown on the right.

Stridulatory file of the male is shown in Fig. 3I. A total of 95 teeth are almost uniform in shape and density over the whole pars stridens.

\section{Isophya brunneri Retowski, 1888}

The range of this species includes the Central Black Earth regions of Ukraine and Russia.

Material. Russia: Kursk district (Central Black Earth State Reserve), vi.1969, 1 male, leg. N. Dubrovin; Southern Crimea: Yalta, 24.vi.1981, 1 male, 2 females, leg. R. Zhantiev; Yalta, Mt. Ai-Petri, vi.1981, 1 female, leg. R. Zhantiev; near Bakhchisaray, v.-vi.1980, 1 male, leg. R. Zhantiev.

Song. Males produce signals consisting of two parts (Fig. 4D): a fast hemisyllable (duration at $22^{\circ} \mathrm{C}$ is $31.6 \pm 0.6 \mathrm{~ms}$, $\mathrm{SD}=2.9$, specimens of Kursk population) containing 8-12 tooth-impacts and series of 9-16 clicks with variable durations (mean $271 \pm 21 \mathrm{~ms}, \mathrm{SD}=93$ ). The first tooth-impact in the series has the highest amplitude compared to that of the syllable. A pause of about $0.5-1 \mathrm{~s}$ divides the syllable and clicks of the second part of the song. The repetition period of the calling signals is ca. $2 \mathrm{~s}$. Females respond to these songs by one to several tooth-impacts.

The frequency spectrum (Fig. 5A) contains several periodical peaks in the band of up to $20 \mathrm{kHz}$ and some additional ones with lower amplitudes around $30 \mathrm{kHz}$.

Pars stridens of this species bears a smaller number of teeth: only ca. 50. Their shape and spatial distribution are almost uniform along the file with a small tubercle with a few densely distributed teeth laterally (Fig. 3J).

\section{Isophya pienensis pienensis Maran, 1954}

This western European species has been recorded in Austria, the Czech Republic, Slovakia, Poland and Transcarpathian Ukraine (Heller et al., 2004; Heller, 2013).

Material. Ukraine: Transcarpathian Ukraine, vill. Mukachevo $\left(48^{\circ} 26^{\prime} \mathrm{N}, 22^{\circ} 42^{\prime} \mathrm{E}\right)$, vi.1987, 1 male, leg. G. Ryazanova.

Song. Males produce single syllables (Fig. 7A) with variable intervals (based on our observations, 1.5 to $4.3 \mathrm{~s}$ ). The duration of the syllables is $411 \pm 14 \mathrm{~ms}(\mathrm{SD}=33.8)$.

The frequency spectrum differs from the spectra of most Isophya studied. It lies in a wider band $(0.1-50 \mathrm{kHz})$ and frequency components outside the main and additional peaks have a higher amplitude than those of other Isophya spp. The main maximum is near $20 \mathrm{kHz}$ and two additional peaks are present in the ultrasound band at 25 and $30 \mathrm{kHz}$ (Fig. 5B).

Male stridulatory file bears numerous (184) teeth. The highest density is on the lateral part of the pars stridens (Fig. 3K).

\section{Isophya stepposa Bey-Bienko, 1954}

This species (Fig. 6C, D) was described from central European Russia (Central Black Earth Nature Reserve near Kursk).

Material. Russia: Central Black Earth State Reserve (Kursk distr.), v.-vi.1969-1982, >50 males and females, leg. N. Dubrovin \& O. Korsunovskaya; Voronezh Region, $80 \mathrm{~km} \mathrm{~S}$ Voronezh, Divnogorye village, vi.2016, 9 males, 2 females, leg. F. Martynovchenko; Rostov Region, locality near Oblivskaya village (4839’ N, 42¹1'E), vi.1990, 1 male, leg. O. Korsunovskaya.

Song. The calling song of males from type locality consists of a continuous sequence of uniform long impulse groups (the first hemisyllable, termed hemisyllable hereinafter in this chapter; at $22^{\circ} \mathrm{C}$ their mean duration is 1144 $\pm 38 \mathrm{~ms}, \mathrm{SD}=76$ ) followed by one or two short afterclicks (the second hemisyllable). The pause between the two parts of the song lasts $186 \pm 6 \mathrm{~ms}(\mathrm{SD}=11)($ Fig. $7 \mathrm{~B})$.

The repetition rate of the hemisyllable at $22^{\circ} \mathrm{C}$ is ca. 0.5 $\mathrm{s}^{-1}$. The period of repetition of the tooth-impacts in the hemisyllable changes from $2-3 \mathrm{~ms}$ in the first $30-40 \mathrm{~ms}$ of the song to $10-12 \mathrm{~ms}$ in the middle part and the final toothimpacts decrease down to $6 \mathrm{~ms}$.

The specimen recorded at Oblivskaya at $23^{\circ} \mathrm{C}$ produced hemisyllables of similar duration $(1272 \pm 12 \mathrm{~ms}, \mathrm{SD}=40)$, but the pause between the hemisyllable and after-click was longer: $340 \pm 5 \mathrm{~ms}(\mathrm{SD}=18)$. The change of the toothimpact repetition rate in the hemisyllable was the same as that recorded for specimens from the type locality.

Females respond to the hemisyllable of the male with a delay similar in duration to the pause between the hemisyllable and the after-click of the male. The female's response is triggered by the end of the male hemisyllable, which consists of one to two short clicks.

The frequency spectrum of the male song is narrow; its main components lie around $20 \mathrm{kHz}$ (Fig. 5C). Sometimes 
the spectrum contains additional peaks at $15-16 \mathrm{kHz}$ (as a rule) and around $25 \mathrm{kHz}$.

Male stridulatory file is slightly curved and bears 355 teeth of uniform shape, size and density over most of its length (Fig. 3L).

\section{Isophya taurica Brunner von Wattenwyl, 1878}

I. taurica (Fig. 6E) is a species endemic to Southern and Eastern (Karadag Mountains) Crimea. The northern boundary of its distribution lies in the mountains near Stary Krym and in hills near Bakhchisaray. Outbreaks of this species are recorded, and gregarious and solitary forms are known. These forms differ mostly in colour: the gregarious form is a much darker green than the solitary individuals and has black spots and bands on the dorsal surface of its body (Tshetyrkina, 1966). The same colour differences occur in other species of Isophya, e.g. I. gracilis. During outbreaks, I. taurica damages some agricultural crops, such as tobacco, grapevine, etc.

Material. Eastern Crimea, Karadag, Koktebel village, v.vi.1966-1980, > 50 males and females, leg. R. Zhantiev; vi.2015, 3 males, 3 females, leg. I. Gomyranov.

Song. Males produce a calling song consisting of two parts (Fig. 7C): a hemisyllable with a duration of $327 \pm 1$ $\mathrm{ms}(\mathrm{SD}=7.4)$ at $23^{\circ} \mathrm{C}$ and, after an interval of $1.3 \pm 0.03$ $\mathrm{s}(\mathrm{SD}=181)$, one to nine (mean $4.1, \mathrm{SD}=2.2)$ after-clicks (final hemisyllable); these clicks are the result of the final closing of the tegmina. Females respond to the end of the first hemisyllable by short loud clicks during or slightly earlier than the second part of the male song. Sometimes they are followed by a group of a few quiet tooth-impacts.

The frequency spectrum lies in the band of $10-80 \mathrm{kHz}$, with the main peak at $15 \mathrm{kHz}$; several additional peaks at 18, 55, and sometimes $78 \mathrm{kHz}$ (Fig. 5D).

Male stridulatory file is slightly curved and bears numerous teeth $(\mathrm{n}=180$, one male); their density decreases considerably towards the medial edge of the tegmen (Fig. $3 \mathrm{M})$.

\section{Isophya modesta rossica Bey-Bienko, 1954}

(Fig. 6F)

Comparison of the temporal patterns in the calling signals of $I$. modesta and $I$. rossica reveals they are very similar (Orci \& Heller, 2004). There are subtle differences in the morphology of these two taxa (including in the structure of the pars stridens). Therefore, Orci \& Heller (2004) treats $I$. rossica as a subspecies of $I$. modesta. The main difference between the two subspecies is the different timing of the female's sound response. Females of the nominative subspecies respond to the end of the second part of the male's signal (series of tooth-impacts). The temporal delay is $102-215 \mathrm{~ms}$. Sometimes a female responds also after the first part of the signal, after a delay of 463-708 ms (Orci \& Heller, 2004).

Material. Central Black Earth State Reserve (Kursk distr.), v.-vi.1969-1982, > 50 males and females, leg. N. Dubrovin, O. Korsunovskaya \& A. Benediktov; Moscow Region $\left(54^{\circ} 26^{\prime} \mathrm{N}\right.$, 38³5'E), 8.vii.2015, 2 males, leg. A. Mikhailenko.
Song. As mentioned above, males of the East European subspecies produce a song with a temporal pattern identical to that of the nominative subspecies (Fig. 7D). The whole signal consists of the first hemisyllable and a series of tooth-impacts (the second hemisyllable) followed by a pause lasting several seconds $(3.1-4.2$, mean $3.9 \pm 0.1)$. Diurnal songs of males often consist only of the first part of the song, which is apparently a territorial signal. Both parts of the song usually can be heard in the evening and at night. Behavioural experiments indicate that the first hemisyllable is necessary and sufficient for receptive females to recognize conspecific song and successfully orientate: females found the singing male but did not respond to him; the initial clicks of the series of tooth-impacts trigger the female's sound response. The male goes to the female when he hears her response (Zhantiev \& Korsunovskaya, 1986).

The duration of the first part of the song (males from Moscow Region) is $160 \pm 2(\mathrm{SD}=7.8) \mathrm{ms}$; the amplitude of the tooth-impacts is the highest at the beginning of the hemisyllable, then it decreases exponentially towards the end. The series of clicks has a very variable duration, because it can contain different numbers of clicks: (12-30). The mean duration of the second part of the song is $509 \pm$ $24 \mathrm{~ms}(\mathrm{SD}=87)$ at $24^{\circ} \mathrm{C}$.

The main components of the frequency spectrum of specimens from Kursk Region occur in a band between 5 and $20 \mathrm{kHz}$. Higher amplitudes are recorded around 10 and $13 \mathrm{kHz}$ (Fig. 5E). The spectra of specimens from the "Moscow" population may have the main peak at 13 (more rarely 15) and additional one or two peaks in the band of $15-19 \mathrm{kHz}$.

Stridulatory file of a male from the Kursk population bears 120 teeth (Fig. 3N), with increasing density at the lateral edge of the tegmen. The size of these teeth is greatest on the medial tegmen edge. This coincides with the structure of the pars stridens in I. modesta modesta (Orci \& Heller, 2004).

\section{Isophya stysi Cejchan, 1957}

The calling song and stridulatory files of west European specimens were studied by Orci et al. (2005). There is data for males from the western Ukrainian (Uzhgorod) population.

Material. Transcarpathian Ukraine, env. Uzhgorod, 3 males, 2 females, vi.1973 (ex larvae), leg. N. Dubrovin.

Song. In the laboratory males produced single syllables with a repetition rate of about $1-2$ per minute. The duration of the syllables was $114.1 \pm 5.6 \mathrm{~ms}(\mathrm{SD}=20.3)$. Each syllable contained 2-4 initial tooth-impacts (duration of each 4-8 ms) and ca. 35 fast tooth-impacts of amplitude increasing towards the middle of the syllable and decreasing at its end (Fig. 7E). The rate of initial clicks is about $50 \mathrm{~s}^{-1}$, the repetition rate of the fast tooth-impacts changes from 100 to $200 \mathrm{~s}^{-1}$.

The frequency spectrum is similar to that of $I$. taurica but with a slight displacement to the higher frequency band. 
Stridulatory file (Fig. 3O) is slightly curved and bears about 100 almost uniform teeth. Only on the medial and lateral edges are several teeth somewhat smaller than on most of the file. The stridulatory file of the $I$. stysi studied differs from that of males from Hungary and Transylvania by the absence of big widely-spaced teeth on the distal edge of the tegmen (Orci et al., 2005).

\section{Isophya sp. 2}

Specimens of this undescribed species were collected near Kharkov (Ukraine) vi.1971, 3 males, leg. N. Dubrovin, and the male calling song was recorded by Zhantiev \& Dubrovin (1977). In this paper we supplement this data with the frequency spectrum.

Song of the male consists of a single repeated syllable (Fig. 1E) with a duration of $420 \pm 27 \mathrm{~ms}(\mathrm{SD}=61)$. The syllable consists of tooth-impacts with different repetition periods. According to the structure, the syllables are divided into four parts of approximately equal duration. The first and the third quartiles of the syllable consist of very densely arranged impulses; their repetition period is about $3 \mathrm{~ms}$. The second and the last parts of the syllable consist of tooth-impacts with a longer repetition period (15-25 ms and ca. $10 \mathrm{~ms}$, respectively). Syllables are repeated at a rate of ca. $0.5 \mathrm{~s}^{-1}$.

The frequency spectrum occupies a band of $0.5-50 \mathrm{kHz}$ with two peaks at $14-16$ and $25 \mathrm{kHz}$ (Fig. 5F).

\section{DISCUSSION}

The sound signals of the species studied can be assigned to three main types. The first includes signals consisting of two syllables (Isophya gracilis, I. kalishevskii, I. schneideri, I. caspica, Isophya sp. 1). The second consists of first a hemisyllable and then a series of after-clicks (toothimpacts). Such songs are produced by $I$. modesta rossica, $I$. stepposa, I. taurica, I. brunneri, I. doneciana and I. altaica. The third consists of single repeats of syllables of uniform shape and duration (I. stysi, I. pienensis, Isophya sp. 2).

In songs of the first type, the second syllable lasts longer than the first syllable. The duration of the first syllable in different species is $11-15 \mathrm{~ms}$ to $240 \mathrm{~ms}$ and the second lasts 80 to $1100 \mathrm{~ms}$ (at $22-26^{\circ} \mathrm{C}$ ). Interval between them is species-specific and varies from ca. $200 \mathrm{~ms}$ to $2-4 \mathrm{~s}$. Males produce both syllables during the full cycle of the opening-closing of their tegmina.

Songs of the second type consist of a long hemisyllable (the first component of the song) and one or several afterclicks (the second component of the song: the final hemisyllable) following after a pause of different durations. The interval between the two parts of the signal varies in different species between $10 \mathrm{~ms}$ and several seconds. The first hemisyllable is produced by a partial movement of the tegmina. After-clicks are produced during the closing phase of the final movement of the tegmina. The duration of the first part of the song varies from ca. $30 \mathrm{~ms}$ to more than $1 \mathrm{~s}$. The number of tooth-impacts in the second part varies from 1 to 30 in different species. In some species and in some specimens of the same species the number of clicks in the series can also vary. Based on our observations, this number is, for instance, 1-9 in I. taurica, and 3-30 in I. m. rossica.

Signals of the third type consist of single syllables with a duration of about 100 and $400 \mathrm{~ms}$, respectively.

Comparing the songs of West European, East European and Caucasian species, one can see that eastern species produce similar songs to western species. But in the eastern part of the range of this genus the calling songs of Isophya spp. have extremely long syllables (I. schneideri and I. stepposa). In addition, the pause between two parts of the songs of the second type is very long: up to 1-1.2 s (I. taurica) or even ca. $5 \mathrm{~s}$ (I. m. rossica).

Comparison of male songs of widespread species (Isophya modesta rossica, I. pienensis) from different populations shows that in general the temporal pattern remains constant throughout their distributions, although they may differ quantitatively. A special case is I. stysi. In spite of the similarity of the songs of specimens from Hungary and Transylvania (Orci et al., 2005) and Ukrainian Transcarpathia, morphological differences in the stridulatory file might indicate the possibility of the existence of a cryptic species and requires further investigation.

The frequency spectra of the Isophya spp. studied occur in a range with an upper border of up to $80 \mathrm{kHz}$. However, in general, they occupy narrower bands with a width from 15 to $50 \mathrm{kHz}$. As a rule, there is only one distinct peak. The dominant frequencies in the spectra of many species are higher than $20 \mathrm{kHz}$. Some species have lower dominant frequencies that are in the audio range (e.g. I. modesta rossica and I. caspica). The spectra of the songs of sympatric species often broadly overlap, but dominant frequencies may differ by $5-6 \mathrm{kHz}$ (e.g. I. m. rossica and I. stepposa occurring in steppe in the environs of Kursk).

The male pars stridens of the species studied can be classified into three main types. In species of the first group (I. caspica stshelkanovtzevi, Isophya sp. 1, I. schneideri, I. doneciana), the stridulatory file bears nearly identical evenly spaced teeth. In species of the second group, tooth density gradually changes on the medial part of the file. In the third group (I. altaica), there is a medial group of larger and more widely spaced teeth.

Isophya males are able to produce calling songs with an irregular or regular repetition rate. The rate of the signals varies in different species from three per second to one per several minutes. In the latter case, acoustic contact between the two sexes distinctly accelerates the rate of repetition of calling.

The Isophya spp. studied by us belong to several groups (Warchalowska-Sliwa et al., 2008; Chobanov et al., 2013, 2017). Species producing songs of the first type mainly belong to the I. speciosa and I. schneideri species groups. Signals of the second group are mainly produced by species of the $I$. pyrenaea and I. modesta species groups. Songs of the third type are peculiar to species of the $I$. kraussii and I. costata groups. Thus, in general, there is a relationship between the taxonomic position of the species and their signal type, but in some cases there is not. Recent work based on morphological, acoustical and molecular- 
genetic characters and data on the distributions of Isophya spp. from Anatolia and the Balkans (Chobanov et al., 2017), elucidates some factors that could affect the evolution of the species studied. As a result of this, there are some contradictions between the phenetic grouping and the phylogeny based on mitochondrial and nuclear markers. Chobanov et al. (2017) suggest a different evolutionary pattern for the genus Isophya. Our opinion is that this is also true for the species studied by us. Moreover, we believe that different characters could evolve at different rates and it is possible that there are some apomorphies in basal taxonomic groups, whereas in terminal groups, by contrast, the plesiomorphic state of a character can be retained. In the case of acoustic communication, this should happen rather easily, because insect behaviour, including acoustic behaviour, is easily changes in response to various factors, both endogenous and exogenous. In our opinion, an extremely important factor in the evolution of acoustic signalling in a species is the interaction with the acoustic signals of sympatric species. One example of such changes, conducive to reproductive isolation, is the considerable difference in signals of the winter and summer generations of the bivoltine species Neoconocephalus triops, which exist in multispecies communities that differ temporally in species compositions and sound signal patterns (Whitesell \& Walker, 1978).

Mechanisms that increase the reliability of acoustic communication between conspecific individuals in some phaneropterids probably include, among others, the following three: (1) presence of species-specific delays in the female response with a corresponding temporal window, during which the response of the female will be identified by the male as conspecific (e.g. Heller \& Helversen, 1986; Zhantiev \& Korsunovskaya, 1986; Zimmermann et al., 1989); (2) selective phonotaxis of males (as in Leptophyes spp.), which ignore the mistaken responses of females (Zimmermann et al., 1989); (3) considerable differences in signal types and their temporal parameters between members of an acoustic community. Thus, under natural conditions Isophya gracilis occurs together with other phaneropterids Poecilimon similis or P. scythicus, which produce series of two or three syllables of equal duration: 350 and $500 \mathrm{~ms}$, respectively (Zhantiev \& Korsunovskaya, 2005). This duration is longer than that of the second syllable of $I$. gracilis and ineffective (Korsunovskaya, 2015). Another sympatric species, $P$. schmidtii, produces very short syllables, and their duration also fails to elicit phonotaxis or a sound response from I. gracilis females. Therefore, females of $I$. gracilis, in spite of the relatively low selectivity of their reaction, are able to distinguish heterospecific signals and successfully mate with conspecific males.

It was shown earlier that different components of the complicated signals of Isophya spp. have different functions (Zhantiev \& Korsunovskaya, 1986, 1990; Korsunovskaya, 2015). Thus, females of I. modesta rossica use the first part of the song (hemisyllable) for recognition of conspecific songs. The second part (series of clicks) acts as a trigger for the female sound response. Similar results were obtained in experiments with other species $-I$. gracilis and I. schneideri. The songs of these Isophya species are of the first type. The first syllable/hemisyllable is sufficient for recognition of conspecifics so that females are able to locate singing males. However, the whole signal consisting of two syllables accelerates phonotaxis in the female and stimulates her to respond by producing sound. The last response is triggered by the second syllable. An acoustic contact between male and female results in the more efficient finding of a mate. The ability of a female to recognize conspecific individuals based on the first syllable suggests that calling songs consisting of one syllable are plesiomorphic and basal in the tree of song patterns of East European and Caucasian species.

ACKNOWLEDGEMENTS. We are grateful to V. Chukanov, I. Gomyranov, D. Lapshin, F. Martynovchenko, A. Mikhailenko, V. Savitsky, D. Tishechkin and A. Semenov for collecting specimens of some species and for the chance to study those specimens, to A. Gorokhov for his help in working with the collections of Orthoptera at the Zoological Institute, Russian Academy of Sciences, and to two anonymous reviewers for comments and corrections that have significantly improved this manuscript. The bioacoustic part of the work was supported by the Russian Science Foundation (14-50-00029 - Scientific basis of the national biobank - depository of the living systems). The morphological studies were performed as part of the research plan of the Department of Entomology, Moscow State University (Federal Research database No. AAAA-A16-116021660101-5).

\section{REFERENCES}

Bey-Bienko G.Y. 1954: Orthoptera Vol. II, Sect. 2. Bushcrickets. Subfam. Leaf Bush-crickets (Phaneropterinae). In: Fauna U.S.S.R. (NS) 59. Inst. Zool. Acad. Sci. URSS, 385 pp. [English translation: 1965, Israel Program for Scientific Translations, Jerusalem].

Chobanov D.P., Grzywacz B., Iorgu I.S., Ciplak B., Ilieva M.B. \& WarchalowsKa-Sliwa E. 2013: Review of the Balkan Isophya (Orthoptera: Phaneropteridae) with particular emphasis on the Isophya modesta group and remarks on the systematics of the genus based on morphological and acoustic data. Zootaxa No. 3658, 81 pp.

Chobanov D.P., Kaya S., Grzywacz B, Warchalowska-Sliwa E. \& ÇıPLAK B. 2017: The Anatolio-Balkan phylogeographic fault: a snapshot from the genus Isophya (Orthoptera, Tettigoniidae). — Zool. Scr. 46: 165-179.

Cigliano M.M., Braun H., Eades D.C. \& Otte D.: Orthoptera Species File. Version 5.0/5.0. [24.12.2016]. URL: http://Orthoptera.SpeciesFile.org

Grzywacz-Gibala B., Chobanov D. \& Warchalowska-Śliwa E. 2010: Preliminary phylogenetic analysis of the genus Isophya (Orthoptera: Phaneropteridae) based on molecular data. Zootaxa 2621: 27-44.

Harz K. 1969: The Orthoptera of Europe. Vol. 1. Dr. W. Junk, The Hague, 749 pp.

Heller K.-G. 1984: Zur Bioakustik und Phylogenie der Gattung Poecilimon (Orthoptera, Tettigoniidae, Phaneropterinae). Zool. Jb. Abt. Syst. Geogr. Biol. Tier. 111: 69-117.

Heller K.-G. 1988: Bioakustik der europaeischen Laubheuschrecken. J. Margraf, Weikersheim. 360 pp.

Heller K.-G. 1990: Evolution and song pattern in Eastern Mediterranean Phaneropterinae: Constrains by the communication system. In Bailey W.J \& Rentz D.C.F. (eds): The Tettigoniidae: 
Biology, Systematics and Evolution. Crawford House Press, Bathurst, pp. 130-151.

Heller K.-G. 2013: Phaneropteridae. In Karsholt O. \& Nieukerken E.J. van (eds): Orthopteroid Orders. Fauna Europaea. Version 2.6.2. URL: http://www.faunaeur.org.

Heller K.-G. \& von Helversen D. 1986: Acoustic communication in phaneropterid bushcrickets: species-specific delay of female stridulatory response and matching male sensory time window. - Behav. Ecol. Sociobiol. 18: 189-198.

Heller K.-G., OrCi K.M., Grein G. \& Ingrisch S. 2004: The Isophya species of Central and Western Europe (Orthoptera: Tettigonioidea: Phaneropteridae). - Tijdschr. Entomol. 147: 237-258.

Hochkirch A., Nieto A., García Criado M., Cálix M., Braud Y., Buzzetti F.M., Chobanov D., Odé B., Presa Asensio J.J., Willemse L. ET AL. 2016: European Red List of Grasshoppers, Crickets and Bush-crickets. Publications Office of the European Union, Luxembourg, $92 \mathrm{pp}$.

IngRISCH S. 1991: Taxonomie der Isophya-Arten der Ostalpen (Grylloptera: Phaneropteridae). - Mitt. Schweiz. Entomol. Ges. 64: 269-279.

IORGU I.Ş. \& IORGU E.I. 2012: Song description of Zubovski's bush-cricket, Isophya zubovskii (Orthoptera: Phaneropteridae). - Trav. Mus. Natn. Hist. Nat. Grigore Antipa 55(1): 57-63.

KoRsUNOVSKAYA O. 2015: Sound communication and recognition of the calling song in bush-cricket Isophya gracilis Mir. (Orthoptera, Phaneropteridae). - Bull. Mosc. Soc. Nat. Biol. Ser. 120(4): $26-30$.

OrCi K.M. \& Heller K.-G. 2004: A description of the song of Isophya modesta modesta (Frivaldszky, 1867) with notes on its relationship to I. modesta rossica Bey-Bienko, 1954. - J. Orthopt. Res. 13: 211-219.

Orci K.M, Nagy B., Szovenyi G., Racz I.A. \& Varga Z. 2005: A comparative study on the song and morphology of Isophya stysi Cejchan, 1958 and Isophya modestior Brunner von Wattenwyl, 1882 (Orthoptera, Tettigoniidae). - Zool. Anz. 24: $31-42$.

RagGe D.R. \& ReYnolds W.J. 1998: The Songs of the Grasshoppers and Crickets of Western Europe. Harley Books, Natural History Museum, London, $591 \mathrm{pp}$.

Sevgili H., Demirsoy A. \& Durmus Y. 2012: Orthoptera fauna of Kemaliye (Erzincan) Kemaliye (Erzincan). - Hacettepe $J$. Biol. Chem. (Suppl.) 40: 317-335.
TSHETYRKINA I.A. 1966: The biology of the injurious Crimean bush cricket Isophya taurica Br.-W. (Orthoptera, Tettigonioidea). - Horae Soc. Entomol. Unions Soviet. 51: 3-45.

UnAL M. 2010: Phaneropterinae (Orthoptera: Tettigoniidae) from Turkey and the Middle East II. - Trans. Am. Entomol. Soc. 136: $125-183$.

Warchalowska-Sliwa E., Chobanov D.P., Grzywacz B. \& MaRYANSKA-NADACHOWSKA A. 2008: Taxonomy of the genus Isophya (Orthoptera, Phaneropteridae, Barbitistinae): Comparison of karyological and morphological data. - Folia Biol. 56: 227-241.

Whitesell J.J. \& WALKER T.J. 1978: Photoperiodically determined dimorphic calling songs in a katydid. - Nature 274: 887-888.

ZhantIEV R.D. 1981: Bioacoustics of Insects. Moscow University Press, Moscow, 256 pp. [in Russian].

Zhantiev R.D. \& Dubrovin N.N. 1977: Sound communication in the genus Isophya (Orthoptera, Tettigoniidae). - Zool. Zh. 56: 38-51 [in Russian, English abstr.].

Zhantiev R.D. \& KorsunovskaYa O.S. 1986: Sound communication in bush crickets (Tettigoniidae, Phaneropterinae) of the European Part of the USSR. - Zool. Zh. 65: 1151-1163 [in Russian, English abstr.].

Zhantiev R.D. \& KoRsunOvSKaYa O.S. 1990: Sound communication of Phaneropteridae (Orthoptera). In Gribakin F.G., Wiese K. \& Popov A.V. (eds): Sensory System and Communication in Arthropods: Advances in Life Sciences. Birkhauser, Basel, pp. 403-406.

Zhantiev R.D. \& KorsunOvSKaya O.S. 2005: Acoustic signals of the bushcrickets of tribe Barbitistini (Orthoptera: Tettigoniidae: Phaneropterinae) from Eastern Europe and Caucasus. I. Poecilimon Fisch., Isoimon B.-Bienko. - Russ. Entomol. J. 14(2): 101-111.

Zhantiev R.D. \& KorsunOvSKaya O.S. 2015: Acoustic signals of the bush- crickets of tribe Barbitistini (Orthoptera, Tettigoniidae, Phaneropterinae) from Eastern Europe and Caucasus. II. Leptophyes Fieber, 1853, Euconocercus Bey-Bienko, 1950, Barbitistes Charpentier, 1825, Polysarcus Fieber, 1853. Russ. Entomol. J. 24(3): 1-10.

ZimmermanN U., RheinLAENDER J. \& RoBinson D.J. 1989: Cues for male phonotaxis in the duetting bushcricket Leptophyes punctatissima. - J. Comp. Physiol. (A) 164: 621-628.

Received July 27, 2016; revised and accepted March 23, 2017 Published online June 9, 2017 